DOI: $10.35619 /$ iiu.v1i13.334

Iryna Perishko

$\mathrm{PhD}$ in Pedagogy, Associate Professor at Practice of the English Language Department, Rivne State University for the Humanities,

Rivne, Ukraine ORCID: 0000-0002-5232-5945, e-mail:perishko_irina@ukr.net Svitlana Vasylkevych Senior Lecturer at the Department of Methodology of Teaching Foreign Languages, Rivne State University for the Humanities, Rivne, Ukraine ORCID: 0000-0003-0006-2810, e-mail: svitlana.vasylkevych@rshu.edu.ua

\title{
GENDER DIFFERENCES IN FOREIGN LANGUAGE LEARNING
}

\begin{abstract}
The paper focuses on influence of gender and academic abilities in learning of foreign languages. The effects of gender and scholastic ability on vocabulary retention and reading comprehension in a foreign language have been determined. Research on gender differences is a disputable issue. The substantial studies on the scientific problem have been analyzed. The authors investigate gender differences in the attitudes and performance of male and female students of various ability levels while dealing with a foreign language task. The article describes gender differences that are important and informative. Though, the issue of gender differences is not distinctive there is a marked differentiation between males and females of high ability adolescent learners. The reasons for the disparity can be the differences in socialization or in learning preferences and styles. The article outlines the factors that have been proposed to account for the imbalance between males and females academically talented learners. The differences in motivation among boys and girls of different ability levels and the differential effect of motivation on individuals who belong to the gender groups are important in deciding the types of activities that would most benefit all students.
\end{abstract}

Keywords: gender differences, learning foreign languages, academic abilities, male and female learners, academic achievement.

Problem statement. For the last several decades, studies involving gender differences have found that males and females differ to some degree in their academic achievement and their academic interests. Some researchers argue against the study of gender differences. The study of gender differences is controversial for a number of well-founded reasons. Though the gender 


\section{Інноватика у вихованні. Випуск 13.Том 1. 2021.}

differences are not clear, it appears to be a marked differentiation between men and women in the population of high ability adolescent learners.

Research publications analysis. The differences are usually deals with social stereotypes which can be the factors pushing girls to choose more verbally oriented subjects such as foreign languages, whereas boys are prone to more quantitatively oriented subjects such as science and math (Reis \& Callahan, 1994). Research made by scholars to counteract the stereotypes have been quite successful over the years and have managed to decrease the gap between the genders significantly, with one notable - the stratum of high ability boys and girls of high-school age and beyond. It is in this particular group that gender differences remain unchanged.

The gap is in favour of males where quantitatively oriented disciplines are concerned. Females have been reported to more frequently choose and to consider less challenging verbal subjects such as foreign languages (OlszewskiKubilius \& Dixson, 2019).

In her study, Caplan (2010) reviews the literature that has shown gender differences in mathematical, spatial and verbal abilities. In discussing verbal ability, for instance, she argues that the staggering number of ways that the construct has been operationally defined by various studies (she lists 32 ), leaves us without a clear understanding of what verbal ability is. She underlines, moreover, that gender differences are not found invariably, they do not exist at all age, and they account for very little of the variance in individual performance.

The aim of the article is to analyze the differences in the attitudes and performance of male and female learners of different ability levels facing with a foreign language task.

Presenting the main research material. The study of Nikolova \& Taylor (2003) showed that the level of ability had a bearing on student scores in a creative reading task, they took their analysis a step further by examining in detail the part gender combined with ability level played in these differences.

The more learner characteristics we can identify as crucial in performance of the tasks, the better we can attune our teaching materials and tools.

Researchers point to the danger of creating a self-fulfilling prophecy by the publication of differences between the genders, and a continuation of biased educational practices that favor one gender over another (Baumeister, 2020).

Furthermore, it is argued that the research on gender differences overemphasizes the differences between sexes and disregards the differences within sexes (Hare-Mustin \& Marecek, 2003). However, Halpern and LaMay (2000) believe that: “... despite the dangers inherent in answering questions about group differences, censorship, even self-censorship, does not promote equality and can be far more dangerous and counterproductive than directly addressing the question. Stereotypes and prejudice are not caused by an open process of scientific inquiry; in fact, they seem to flourish in the absence of data" (p. 233).

Nevertheless, it is not our intention to dismiss the cautions about research on gender differences. However, keeping these cautions in mind, we continue to 


\section{Інноватика у вихованні. Випуск 13.Том 1. 2021.}

concur with the opinion of Halpern and LaMay (2000) that research in sex differences is important and informative.

However, the problem of sex differences is not distinctive, as stated before, there appears to be a marked differentiation between boys and girls of high ability adolescent learners. Some reasons for the discrepancy may be differences in socialization or in learning preferences and styles.

Study of sex differences in talented students has demonstrated that academically talented female learners can be socialized to hide their talents. Female students often believe they should decide between academics and being found "socially valuable" (Noble, 1996, p. 49). Research showed that academically talented females underachieved in comparison with academically gifted males. Moreover, there is little institutional support at the university level for the females and even when there is this support, females do not often seek such programs. According to Noble, at least half of the learners at the elementary level identified as gifted, talented or highly capable are girls, but by junior high school females are less than a quarter of talented learners. She underlines that most academically talented females have had occasion to hide their abilities to survive socially, having been conditioned by parents and teachers to see themselves as less capable than men, to avoid risk-taking, and to have lowered expectations for success. In addition, both female and male teachers seem to perceive those same qualities that they view positively in academically talented men as negatives in women.

There might be sex differences in learning style preferences as well. There is opinion of Dimitrov (2010), who found that high ability junior high school male have a predilection for open-ended tasks and score better than high ability female at the same grade level when confronted with more creative tasks. Other factors which have been proposed to account for the discrepancy between boys and girls academically gifted students are issues of assertiveness, fear of success, and external versus internal attribution of ability.

Verbal ability is an area in which female students have consistently shown superiority to male students. Nevertheless, in a meta-analysis of 165 studies representing over a million subjects, scholars state negligible gender differences in seven verbal abilities including general verbal ability and vocabulary.

In a similar vein, there has been much evidence that girls are better language learners than boys. The research of Lynn and Wilson (1993) is particularly interesting. They studied students learning Irish in Ireland between ages of 8 and 14. As the learning of Irish as the second language (L2) is required for all students, it gave the scholars a possibility to study L2 learners across the whole ability range, rather being restricted to the more select number of students who learn a foreign language in countries such as the United States. Substantial differences were found favoring female and the differences remained constant throughout secondary school. These findings led the authors to reject the explanation of social expectations theory that society expects female to be good language learners, and that secondary schoolgirls are more conscious of 


\section{Інноватика у вихованні. Випуск 13.Том 1. 2021.}

conforming to these expectations than primary schoolgirls. Instead, they favor the theory that gender differences have a biological basis.

On the other hand, Cross (1983) found that male outperformed female on a battery of nine French tests. He attributed this to the fact that the teachers were male, providing a role model for the men. Role modeling of teachers as a factor in the boys' performance in foreign languages was touched upon by Clark and Trafford (2007). Though, according to them, teachers tended to dismiss the effect of teacher's gender on male performance, the authors point out that in a certain school where boys scored above the national average, two highest achieving classes were both taught by males who shared interests with the boys.

Research specifically examining gender differences in L2 vocabulary learning has been also inconclusive.

Another area of research relevant to our subject is that of gender and using of computers. It has been stated that men show more interest in computers than women. They use computers more and in general have a more positive attitude and less anxiety. Nevertheless, more recent research has shown that this difference has diminished, with previous experience being better indicator than gender for attitude and performance. Grace (2000) has not found sex differences in the ability of students beginning a foreign language to retain vocabulary from a dialogue, while Meunier (1995-1996) found that performance was more related to personality differences and keyboard control than to sex differences.

Gender differences in reading comprehension of L2 text have been shown for the factors of topic familiarity, background knowledge and interest. Bügel \& Buunk (1996) found text biases differentially affecting boys and girls in the Dutch national examinations of foreign languages (French, English and German) reading comprehension. They found that girls do better with topics of education, human relations, art and philosophy, while boys do better on economic and technological topics, politics, sports and violence. In fact, the commonly held belief, that in general girls are better readers than boys, does not seem to hold up beyond elementary school.

We venture here another speculation based on findings in the research by Dimitrov (2010), according to which boys and namely high ability boys are more motivated and with better scores on open-ended, creative tasks than girls. It is not possible then to claim that for a male the status of high ability student is often achieved thanks to a more creative and more adventurous mindset, while a female is more likely to reach this status through hard work and a predilection for more traditional academic tasks?

Certainly, the results by Nikolova and Taylor (2003) for reading comprehension do not support the contention that girls are better L2 readers than boys, but the authors make more clear findings that average ability students are hindered by the task. Now we know that both males and females are about equally affected. We do not have certain answer as to why should be a gender factor for vocabulary recall but not for reading comprehension. Perhaps motivation can less affect performance in reading comprehension than vocabulary retention. It would not seem to be any incentive for students to learn 


\section{Інноватика у вихованні. Випуск 13.Том 1. 2021.}

vocabulary items while reading the passage. It could be argued also that the difficulty of the task was detrimental to understand, arguably a more difficult process than vocabulary recall.

Conclusion and further research prospects. To sum up, we believe that motivation is the overriding factor to consider while interpreting study results. The differences in motivation among males and females of various ability levels and the differential effect of the motivation on individuals belonging to these gender groups are important to decide the kinds of activities that would most benefit all learners. Ability and gender are students' variables that have not been widely investigated in foreign language studying and less taken together. Despite the fact that there are real dangers to overemphasize on gender differences, we believe that this work demonstrates the importance of attempting to match activities with individual learners to optimize studying foreign languages. These are very important issues for further study.

\section{REFERENCES}

Reis, S., \& Callahan, C. (1994). Attitudes of adolescent gifted girls and boys toward education, achievement, and the future. Gifted Education International, No 9 (3), 144-151.

Olszewski-Kubilius, P., \& Dixson, D. (2019). Gifted students. Annual Review of Psychology, 70, 551-576. URL: https://doi.org/10.1146/annurevpsych-010418-102846. [Accessed 12.05.21].

Caplan, P. (2010). Teaching Critical Thinking about Psychology of Sex and Gender, URL: https://doi.org/10.1111/j.1471-6402.2010.01605.x. [Accessed 12.05.21].

Nikolova, O., Taylor, G. (2003). The Impact of a Language Learning Task on Instructional Outcomes in Two Student Populations: High-Ability and Average-Ability Students, [online] URL: https://doi.org/10.4219\%2Fjsge-2003436. [Accessed 12.05.21].

Baumeister, R., Reynolds, T., Howard, C. (2020). Man up and take it: Gender bias in moral typecasting. Organizational Behavior and Human Decision Processes, Vol.161, 120-141.

Hare-Mustin, R., \& Marecek, J. (2003). Psychology of women and genderю URL: https://doi.org/10.1002/0471264385.wei0112

Halpern, D., \& LaMay, M. (2000). The smarter sex. A critical review of sex differences in intelligence. Educational Psychology Review, No 12 (2), 229-246.

Noble, K. (1996). Resilience, resistance, and responsibility: Resolving the dilemma of the gifted woman. In K.D. Arnold, K.D. Noble, \& R.F. Subotnik (Eds.), Remarkable women: Perspectives on female talent development ( $\mathrm{pp}$. 413-423). Cresskill, NJ: Hampton.

Dimitrov, D. (2010). Gender Differences in Science Achievement: Differential Effect of Ability, Response Format, and Strands of Learning Outcomes, URL: https://doi.org/10.1111/j.1949-8594.1999.tb17507.x. [Accessed 12.05.21]. 
Lynn, R., \& Wilson, R. (1993). Sex differences in second language ability. School Psychology International, 14, 275-279.

Cross, D. (1983). Sex differences in achievement. System, No 11, 159162.

Clark, A. \& Trafford, J. (2007). Return to gender: boys' and girls' attitudes and achievements. URL: https://doi.org/10.1080/09571739685200371. [Accessed 12.05.21].

Grace, C. (2000). Gender differences: Vocabulary retention and access to translations for beginning students of CALL. The Modern Language Journal, 84 (2), 214-224.

Meunier, L. (1995-1996). Human factors in a computer assisted foreign language environment: The effects of gender, personality and keyboard control. Calico Journal, No 13 (2 \& 3), 47-72.

Bügel, K., \& Buunk, B. P. (1996). Sex differences in foreign language text comprehension: The role of interests and prior knowledge. The Modern Language Journal, 80, 15-31.

\title{
ГЕНДЕРНІ ВІДМІННОСТІ У НАВЧАННІ ІНОЗЕМНОЇ МОВИ
}

\author{
Перішко Ірина \\ кандидат педагогічних наук, доцент, \\ доцент кафедри практики англійської мови \\ Рівненського державного гуманітарного університету, \\ м. Рівне, Україна \\ ORCID: 0000-0002-5232-5945, \\ e-mail:perishko_irina@ukr.net
}

Василькевич Світлана старший викладач кафедри методики викладання іноземних мов Рівненського державного гуманітарного університету, м. Рівне, Україна ORCID: 0000-0003-0006-2810, e-mail: svitlana.vasylkevych@rshu.edu.ua

Анотація. Стаття присвячена проблемі впливу гендерних відмінностей на вивчення іноземних мов, також описано значення статі й академічних здібностей учнів на розуміння читання іноземною мовою та засвоєння словникового запасу. Оскільки дослідження гендерних відмінностей $є$ спірним питанням, у роботі проаналізовано суттєві дослідження з даної наукової проблеми. Автори досліджують гендерні відмінності у ставленні та успішності студентів різної статі й різного рівня здібностей під час виконання завдань з іноземної мови. У статті описані гендерні відмінності, які є важливими та інформативними. Хоча питання гендерних відмінностей не $є$ характерним, існує помітна диференціація між дівчатами й хлопцями з високими здібностями, що вивчають іноземну 


\section{Інноватика у вихованні. Випуск 13.Том 1. 2021.}

мову у підлітковому віці. Причинами диспропорції можуть бути відмінності в соціалізації або у навчальних уподобаннях та стилях. У статті окреслюються фактори, які були запропоновані для врахування дисбалансу між академічно обдарованими учнями обох статей. Гендерні відмінності, як правило, стосуються соціальних стереотипів, що можуть бути факторами, які схиляють дівчат до вибору більш вербально орієнтованих предметів, таких як іноземні мови, тоді як хлопці схильні до більш кількісно орієнтованих предметів, таких як фізика й математика. У статті зазначається, що чим більше характеристик учня ми можемо визначити як вирішальні для виконання завдань 3 іноземної мови, тим краще зможемо підібрати навчальні матеріали та засоби. Різниця в мотивації серед хлопців і дівчат різного рівня здібностей та диференційований вплив мотивації на осіб, які належать до гендерних груп, є важливими при виборі видів діяльності, які найбільше принесуть користь усім учням і студентам. Здатність та стать - це показники, які не були широко досліджені щодо вивчення іноземних мов, і незважаючи на той факт, що існує небезпека при надмірному акцентуванні уваги на гендерних відмінностях, дана стаття демонструє важливість підбору видів діяльності для індивідів для оптимізації вивчення іноземних мов.

Ключові слова: гендерні відмінності, вивчення іноземних мов, академічні здібності, жіноча та чоловіча статі, навчальні досягнення.

Стаття надійшла до редакиіï 18.02.2021p. 